\title{
Ambrette Seed Oil
}

National Cancer Institute

\section{Source}

National Cancer Institute. Ambrette Seed Oil. NCI Thesaurus. Code C107260.

The oil extracted from the seeds of Abelmoschus moschatus. Ambrette seed oil is used for aches and stiffness and for its aromatic properties. 